University of Texas Rio Grande Valley

ScholarWorks @ UTRGV

Public Affairs and Security Studies Faculty

Publications and Presentations

College of Liberal Arts

$5-10-2021$

\title{
Environmental education and awareness: the present and future key to the sustainable management of Ramsar convention sites in Kenya
}

Parita Shah

George Atisa

The University of Texas Rio Grande Valley, george.atisa@utrgv.edu

Follow this and additional works at: https://scholarworks.utrgv.edu/pass_fac

Part of the Public Affairs, Public Policy and Public Administration Commons

\section{Recommended Citation}

Shah, P., Atisa, G. Environmental education and awareness: the present and future key to the sustainable management of Ramsar convention sites in Kenya. Int Environ Agreements 21, 611-630 (2021).

https://doi.org/10.1007/s10784-021-09534-7

This Article is brought to you for free and open access by the College of Liberal Arts at ScholarWorks @ UTRGV. It has been accepted for inclusion in Public Affairs and Security Studies Faculty Publications and Presentations by an authorized administrator of ScholarWorks@ UTRGV. For more information, please contact justin.white@utrgv.edu, william.flores01@utrgv.edu. 


\title{
Environmental education and awareness - The present and future key to the sustainable management of Ramsar Convention sites in Kenya
}

\author{
Parita Shah $^{1}$ and George Atisa ${ }^{2}$ \\ ${ }^{1}$ Department of Geography and Environmental Studies \\ The University of Nairobi, P.O Box $30197-00100$ \\ Nairobi, Kenya \\ Email:parita@uonbi.ac.ke \\ ${ }^{2}$ Corresponding author \\ Department of Public Affairs and Security Studies \\ University of Texas Rio Grande Valley \\ Edinburg, Texas 78539, USA \\ Email: george.atisa@utrgv.edu
}

\begin{abstract}
The Ramsar wetland sites are important habitats for biodiversity and provide ecological services to communities that otherwise have no access to water resources. In Kenya, some wetlands are more prominent and are recognized worldwide as tourist hot spots, biodiversity-rich zones and wildlife habitats. However, these wetlands face overexploitation and degradation from surrounding communities. The efforts to halt underlying threats and the projected declines in the size and quality of inland wetlands at local levels are not sufficient. The question guiding this study is as follows: to what extent do a Ramsar designation and formal and informal education support communities and institutional efforts in the protection of inland wetlands? This research was conducted at inland wetland lakes of Naivasha, Nakuru and Bogoria that have been designated as Ramsar sites to examine the extent to which existing education has influenced communities' efforts in protecting wetlands. Primary data were collected via questionnaire from three study sites. Using both descriptive and inferential statistics, a logistic regression to determine the significance of various predictor variables, including education, for changes in biodiversity as a proxy for wetlands protection outcomes was performed. The results indicated that education, awareness and other key variables that were expected to support wetlands protection had no significant impact on changes in biodiversity. The study concludes that the designation as Ramsar Convention-protected status alone cannot stop the degradation of inland wetlands in an environment where existing formal and informal education has not empowered communities and institutional efforts.
\end{abstract}

\section{Key Words:}

Ramsar Convention . education and awareness . institutions . communities . lakes

Acknowledgement

This research was made possible by funding from the Dean's Committee in 2014 and 2015, Faculty of Arts, College of Humanities and Social Sciences, University of Nairobi, Kenya. 


$\begin{array}{ll}\text { Abbreviations } \\ \text { CEPA } & \text { Communication, Education, Participation and Awareness } \\ \text { COP } & \text { Conference of Parties } \\ \text { GoK } & \text { Government of Kenya } \\ \text { KWS } & \text { Kenya Wildlife Service } \\ \text { WCK } & \text { Wildlife Clubs of Kenya } \\ \text { WWF } & \text { World Wildlife Fund }\end{array}$

\section{Introduction}

The negative impact of human activities such as agriculture, urbanization, settlement and waste disposal on wetlands globally has been rising steadily over the years. The creation of the Ramsar Convention (RC) on Wetlands in 1971 to protect these areas has prompted the continued designation of protected wetlands all over the world (Mathews 1993) to help strengthen the protection of these water bodies. Ramsar wetlands are protected from destruction in perpetuity (Mathews 1993), but knowledge of the human behavior that has continued to negatively affect the wetlands, especially in developing countries, is as incomplete as scientific knowledge of the dynamics of ecosystems (Breitmeier et al. 2006, pp. 191). Emphasis on education as an approach to understanding both human behavior and ecosystem dynamics is seen as one way to respond to wetlands protection challenges (Loucks and van Beek 2017). Horvat (2008) argues that negative attitudes towards wetlands and lack of knowledge regarding their value are the reasons they continue to face encroachment and degradation.

This study has two primary objectives: (i) to determine if formal and informal education is a significant factor that supports institutions, pragmatic activities and organized efforts nationally and locally in the implementation of wetlands protection policies and (ii) to explore the local community's understanding and knowledge of the RC's goals, local attitudes towards wetlands and the constraining factors that hinder the adoption and implementation of wetlands protection initiatives. To recommend appropriate management approaches, we attempted to find answers to the following question: to what extent do a Ramsar designation and formal and informal education support communities and institutional efforts in the protection of inland wetlands? 
The study was conducted around three Ramsar sites, Lake Naivasha, Lake Nakuru and Lake Bogoria in Kenya, using a survey questionnaire. These three study sites face similar demands related to settlement, water withdrawal, urbanization encroachment and pollution such that their capacity to supply much needed and valuable environmental services continues to decline (Shah 2016). Primary data on gender, years stayed near the wetland, distance from home to the wetland, educational level starting from primary school up to university, the job the respondent is holding, and awareness that $\mathrm{RC}$ is present on the ground were collected alongside other factors that support or constrain wetlands protection. As no standardized and generally accepted measurement of biodiversity improvement exists, protection outcomes associated with species count or ecosystem observations can approximate biodiversity changes (Alvarado-Quesada and Weikard 2017; Weitzman 1988). "The most important role of wetlands is maintaining biodiversity" (Farnandez and Emeterio 2017), and this is also a reflection of the RC pillar of "wise use" outcomes. Therefore, improved biological resources (specific taxa of birds, plant and animal communities, and organisms) as seen by the communities were used as a proxy in measuring success or failure of wetlands protection.

Wetlands are defined by Article 1 of the RC as "areas of marsh, fen, peatland or water, whether natural or artificial, permanent or temporary, with water that is static or flowing, fresh, brackish or salt, including areas of marine water the depth of which at low tide does not exceed six meters". Wetlands vary according to their geographic location, water quality, dominant plants and soil characteristics (Mitsch and Gosselink 1993; Maltby 1986). Wetlands are sources of environmental services that are beneficial to humans and have ecological value for society as a whole (Raimondo et al. 2019). The RC divides wetlands into three categories: marine/coastal; inland wetlands such as lakes and rivers; and man-made wetlands. The focus of this research was on inland wetlands.

Inland wetlands fall into the "isolated wetlands" classification, and their hydrological supplies are rainfall and surface runoff. They are often the only source of environmental services, including freshwater for a wide range of uses and recreation, to communities in the immediate vicinity. By virtual of their isolation, these lands face serious threats that include encroaching urbanization, agricultural activities, pollution in general and other settlement-related challenges (Raimondo et 
al. 2019; MA 2005). We posit that education, knowledge and awareness are important drivers for a society in regard to translating policy preferences into desired policy outcomes.

Lack of or insufficient education is the reason why wetlands, as providers of environmental services and natural functions that support human wellbeing, continue to be degraded, polluted and diminished by human activities (Polajnar 2008). Various studies have found that the main factors that contribute to awareness of environmental problems in communities are age, vocation, and education (Polajnar, 2008; Pes 1998). It can be difficult to engage in constructive dialogue on the impact of anthropogenic activities on wetlands if the awareness and education gap between experts and the public is large (Do et al. 2014). Do et al. (2014) argue that a community's interest in wetlands protection can be effectively increased through raising awareness using public sector institutions and enhanced via education. For this reason, the RC has developed educational programs designed to improve public awareness and community participation.

Adequate research on the ability of formal and informal education and awareness to promote the adoption of globally designed conservation policies has not yet been conducted (Atisa 2020a; Ramsar Convention 2015). This study contributes to the existing literature as it seeks to link formal and informal education in schools, the jobs that people hold and awareness to wetlands protection outcomes. Teaching environmental education in schools or through informal channels within communities is insufficient if it cannot influence settlements and urbanization towards protecting vulnerable wetlands. This study estimates the significance of the knowledge from both formal and informal education as well as the types of occupations held by the communities in protecting local wetlands. Most of the literature agrees that education is one way to communicate to communities the value and importance of increasing stewardship towards wetlands (Smaldon 2013), but the studies do not go sufficiently far to determine whether it has significant outcomes. Knowledge on wetlands does influence behavior related to their protection, and a lack of knowledge can be linked to their destruction (Farnandez and Emerio 2017); however, this depends on the type of knowledge. Therefore, determining if the knowledge that is taught in schools and to communities has any significant impact influencing activities around the wetland and improving wetland's protection is important. 
While local and informal education have been regarded as foundational to protecting local wetlands (Russi et al. 2013), this is changing as many negative impacts (climate change and migration) that originate outside local jurisdictions are beginning to impact local resources. Formal education, as a platform for understanding and improving conservation, needs to be broadened to encompass the greater public good as well as the career and occupational development of individuals. When there is not a broad approach to learning, unique and locally evolved techniques to protect wetland ecosystems are less effective. A need for new and different legal as well as social institutions that extend the basis for protecting wetlands beyond the importance of their value to local communities is necessary.

The continuing evolution of threats to wetlands is the reason this study seeks to determine the impacts of education, awareness and local perceptions on policies advanced through the RC. First, conservation education and awareness within communities do not correspond to the efforts required to halt underlying threats and the projected declines in the size and quality of inland wetlands. Second, population growth, economic activity and urbanization have not triggered major land use issues for either national or local governments in their response to the challenges of wetlands management and protection in Kenya. Land use laws are weak and leave ample room to continue promoting settlement indiscriminately, even close to vulnerable and fragile landscapes (Atisa et al. 2014). While to communities it seems beneficial to settle on lands close to wetlands, as these are seen as highly fertile and provide easy access to water, in reality, this amounts to destroying the natural base of resources that support the existence of such waters. Education is therefore an important element in helping local governments and traditional institutions understand why settlements and growth need to be controlled around wetlands. The emerging interaction between wetlands and communities requires new criteria for policy approaches from governance, institutional, legal and technical perspectives to prevent further degradation of endangered wetlands (Shah 2020; Millennium Ecosystems Assessments 2005).

Kenya ranks $18^{\text {th }}$ among countries with the least sustainable access to improved water sources in Africa, and more than 320 million people have no access to clean water in sub-Saharan Africa (De Troyer et al. 2016). Even in countries that rank high in sustainable access to water supply, this ranking is relative, and there are currently no quick fixes to water quality and quantity supply challenges in many parts of the world. Therefore, the concept of wetlands protection transcends 
global, national and local jurisdictions. Article 5 of the RC states that there should be consultation and cooperation between countries (in the case of shared wetlands), communities and other stakeholders through education and public participation. The education aspect was adopted at the Conference of Parties (CoP) 7 under the Communication, Education, Participation and Awareness (CEPA) outreach program. The CEPA is continuously being strengthened at every CoP, and countries are being encouraged to develop their national CEPA Action Plans and forward them to the Convention Secretariat.

\subsection{The Ramsar Convention}

"The Convention on Wetlands is an intergovernmental treaty that provides the framework for national action and international cooperation for the conservation and 'wise use' of wetlands and their resources" (Ramsar.org). The Convention on Wetlands is also known as the Ramsar Convention, named after the Iranian town of Ramsar in which it was negotiated on February 3, 1971 (Matthews 1993). The RC was the first intergovernmental treaty formed to conserve natural resources by restraining member countries from selfish overexploitation of wetlands (Matthews 1993). The RC was first adopted by 18 nations, but its adoption has since expanded to 171 contracting parties. Because of the many countries that are party to RC, it is known as a multilateral agreement or, as with all environmental agreements, a multilateral environmental agreement (MEA) (Gardner and Davidson 2011). The Ramsar policies are implemented through three pillars: (i) the "wise use" approach to wetlands, (ii) the designation and management of Wetlands of International Importance and (iii) international cooperation on the management of shared resources and the sharing of knowledge and information (Gardner and Davidson 2011). Treaties rely and work with other partners within countries to promote and implement globally developed policies.

Several other treaty conventions are related to the RC. Those that are most relevant to the study area include the following:

- The Convention on Migratory Species (CMS) and the Convention on International Trade in Endangered Species (CITES). Many globally threatened plants, birds and animal species covered by the CMS and CITES are dependent on wetlands. These two conventions are related to the study lakes as they are home to fish, migratory birds, elephants and rhinos that are classified as endangered. 
- The Convention on Biological Diversity (CBD). The RC is officially recognized as the CBD's "lead implementation partner" on wetlands. "Implementation of the commitments under the RC is simultaneously an implementation of the CBD commitments across thematic and crosscutting programs of work" (Davidson 2018). All three study locations are locations rich in biodiversity that are facing similar threats related to settlements and pollution.

- The World Heritage Convention (WHC). Almost all WHC sites are or include wetlands (Davidon 2018). The Kenya Lake System in the Great Rift Valley is inscribed in the UNESCO "World Heritage list and presents an exceptional range of geological and biological diversity of natural beauty" (https://whc.unesco.org/en/list/1060.

\subsection{National and local wetlands management challenges}

Kenya signed the Ramsar Convention on 5 October 1990 and ratified it on 5 June 1991. In order to successfully implement the RC, the country has developed several legal frameworks and policies that are designed to create awareness and educate communities on environmental conservation. These include the Wetlands Conservation and Management Policy (GoK, 2015), Wetlands Conservation and Management Act (GoK, 2013b), Environment Policy (GoK, 2013a), Sessional Paper No. 6 on Environment and Development (GoK, 1999b), the National Constitution of Kenya (GoK, 2010) and the Environmental Management and Coordination (Conservation and Management of Wetlands) Amendment Regulations (2017). In addition, by 2012, when the CoP 12 was held in Romania, Kenya had developed a national plan including subnational plans, basinlevel plans and site-related plans, in line with the CEPA program (KWS 2012). Despite these developments, some literature has found that government-led conservation actions always fall short of the desired outcomes (Thew 2018).

The reason for this failure to achieve desired conservation outcomes is inadequate engagement with community efforts, perceptions and socioeconomic needs due to lack of education and awareness on the part of communities (Macharia et al. 2010; Breitmeier et al 2006 pp 224). Implementation gaps in government-led initiatives are magnified when all stakeholders are not well-informed (Macharia et al. 2010). To create well-informed stakeholders, families, neighbors, and communities should be educated to enhance conservation outcomes and improve management (Atisa 2020b; Bridgewater 2008). The preamble of the RC states that contracting parties recognize 
the "interdependence of man and his environment" and the need to halt progressive encroachment on wetlands now and in the future (Bowman 1995). Communities must understand this interdependence as well as why they should protect wetlands. This is knowledge that can be gained only through education and awareness.

Better conservation outcomes are always obtained through partnerships. Partnerships provide platforms for the cross-pollination of scientific knowledge, education and skills and cultural understanding among all actors (Atisa 2020b; Ibrahim et al. 2012). A partnership founded on a framework that links local actors such as youth, schools and community-based organizations with nonlocal actors facilitates constructive dialogue among all stakeholders that can deliver the desired wetlands protection outcomes (Breitmeier et al. 2006 pp 193). Partnerships do not work automatically once established, as there is no blueprint or uniform approach for many conservation needs (Atisa 2020b). An assessment of the site-, location- and resource-specific factors that can hinder the adoption of global policies in local settings is necessary (Atisa 2020b). The policies proposed by the $\mathrm{RC}$ are constrained by factors that drive settlements and migration towards proximity to wetlands. These factors include weak national and local land use regulations, limited economic opportunities in many local areas, scientific knowledge, educated local populations and exposure to global policies. We therefore hypothesize the following:

H1: Formal and informal education increases awareness among the communities and therefore is a significant factor in the protection of inland wetlands.

H2: Awareness of why the international, national and local organizations are involved in conservation improves support towards environmental conservation and is a significant factor in the protection of inland wetlands.

\section{Methods and data}

Three study sites were selected, namely, Lake Naivasha, Lake Nakuru and Lake Bogoria, all in the Rift Valley in Kenya. These three lakes have RC protected status and are in the same physiogeographic region. However, while Lake Naivasha and Lake Nakuru are surrounded by more urban and modern agriculture-based activities, Lake Bogoria is surrounded by pastoral and rural farming communities. Educational institutions are more developed around Lake Naivasha and Lake Nakuru but less developed around Lake Bogoria. 


\subsection{Description of the study areas}

The study area consisted of three lakes in the East African Rift Valley, namely, Lakes Nakuru, Naivasha and Bogoria, as shown in Figure 1. Lakes Nakuru and Bogoria are saline lakes, while Lake Naivasha is a freshwater lake.

Figure 1: Location of the study lakes in the Rift Valley

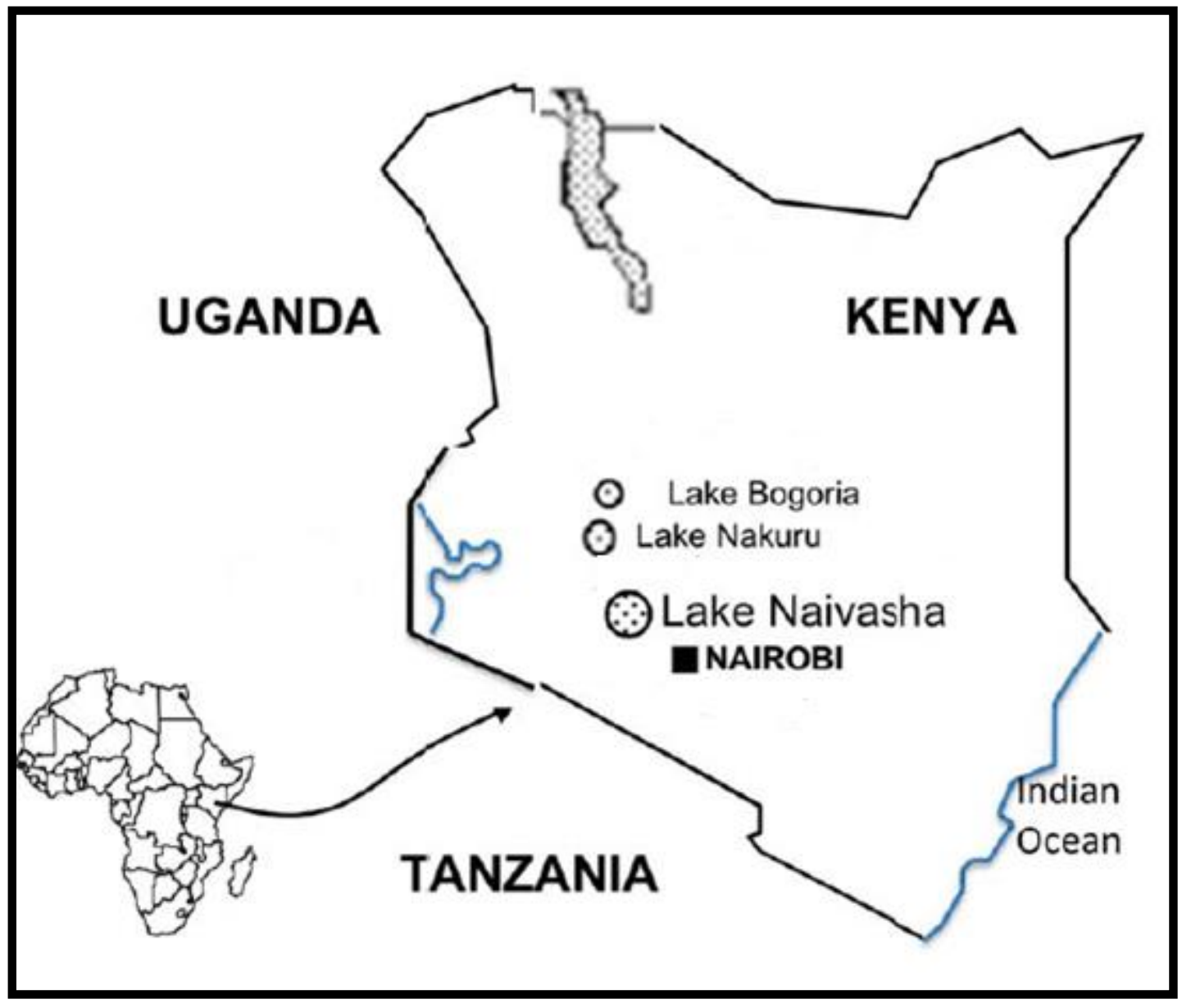

Lake Nakuru is a closed basin lake within Lake Nakuru National Park in Nakuru County. It lies between $0^{\circ} 19^{\prime} 24^{\prime} \mathrm{S}$ and $36^{\circ} 04^{\prime} 07^{\prime} \mathrm{E}$. The size of the lake is $44 \mathrm{~km}^{2}$, and the catchment area is $1,800 \mathrm{~km}^{2}$ (KWS 2002; Thampy 2002; WWF 2000). The name Nakuru comes from the Maasai word "en-akuro", which means "swirling dust" (KWS 2005a). This name refers to the fact that when the lake dries up, white salts mix with dust and are blown by the wind. The lake is supplied with water by seasonal rivers, which include the Makalia, Nderit, Njoro and Larmudiac Rivers. The lake has an introduced fish species, tilapia (Oreochromis alcalicus grahami), which has 
attracted many consumers, such as water birds (KWS 2005b). The lake is home to millions of flamingos, including the greater flamingo (Phoenicopterus rubberroseus) and the lesser flamingo (Phoenicopterus minor). The lake and the park have been identified as an International Bird Area (IBA) (Raini 2009), as over 450 waterfowl species have been recorded (KWS 2011). Lake Nakuru is the country's first Ramsar site (No. 476) and was designated in 1990.

Lake Naivasha is a shallow-basin freshwater lake that lies between $0^{\circ} 45^{\prime} \mathrm{S}$ and $36^{\circ} 26^{\prime} \mathrm{E}$ (Becht and Harper 2002; Everard and Harper 2002). It is the second largest freshwater lake in Kenya and has a catchment size of $3,400 \mathrm{~km}^{2}$. The lake has two rivers draining into it, the Gilgil River and the Malewa River, and has no surface outlet. The lake is an IBA with over 470 bird species that include the fish eagle (Haliaeetus vocifer) and flamingos. This is a very delicate site in Kenya, as it was almost transferred to the Montreux list of threatened sites in 2008 (Peck 2008) due to problems including the uncontrolled pollution of the lake. In contrast to Lakes Nakuru and Bogoria, this lake consistently faces deforestation in its basin and is experiencing increased reduction in water levels and deterioration of lake water quality, fish mortality and decreasing fish stock, increased encroachment and transformation of the lake shore riparian zone, invasive species, increased population and unplanned settlement (WWF 2011b). This lake is surrounded by private land and is not legally gazetted as a protected area under Kenyan law. Before 2010, the riparian land was under the custody of the Lake Naivasha Riparian Association formed in 1927. However, under the new constitution, the national government has custodianship of this land (GoK 2010).

Lake Bogoria lies between $0^{\circ} 11^{\prime} 20^{\prime} \mathrm{N}$ and $36^{\circ} 07^{\prime} 08^{\prime} \mathrm{E}$ and has an area of $34 \mathrm{~km}^{2}$. It is an endorheic water body. The lake is supplied with fresh water by the Waseges, Loboi, Igwamiti and Subukia Rivers. The lake is an IBA with over 310 species of birds, including 70 water birds. It is a home to three threatened species, namely, the great crested grebe (Podiceps cristatus), African darter (Anhinga rufa) and white-backed duck (Thalassornis leuconotus) (WWF 2011a). The reserve is a very important site, as many paleoarctic birds move temporarily to the area during the European winter. It is a major feeding place for flamingos in the East African Rift Valley. Lesser flamingos are abundant here, as they feed on Spirulina platensis (Owino et al. 2001). 
Table 1. Designation of the Sample Lakes as Ramsar Sites

\begin{tabular}{ll}
\hline \multicolumn{1}{c}{ Date Designated } & \multicolumn{1}{c}{ Reason for designation } \\
\hline $\begin{array}{l}\text { Lake Nakuru - June 5, 1990. Ramsar } \\
\text { site number 476. }\end{array}$ & $\begin{array}{l}\text { Lake Nakuru is home to globally endangered } \\
\text { mammals such as the black rhino and hippos and bird } \\
\text { species such as flamingoes. It supports 1\% of the } \\
\text { lesser flamingo population (Criterion VI for Ramsar } \\
\text { sites). } \\
\text { Lake Naivasha - October 4, 1995. }\end{array}$ \\
Ramsar site number 724. & $\begin{array}{l}\text { for more than 350 resident and migrant bird species, } \\
\text { including 1\% of the world Fulica cristata population; } \\
\text { fish; and hippos and waterbucks, around the riparian } \\
\text { parts of the lake. } \\
\text { This is a refuge site for the lesser flamingo and more } \\
\text { than 300 bird species. It is also a habitat for } \\
\text { endangered mammals such as the greater kudu. }\end{array}$ \\
\hline
\end{tabular}

\subsection{Methods}

A survey using structured interviews was carried out between January 2012 and November 2013 and again from November 2014 to December 2016. The target population was heads of households of all communities living near the studied lakes, local government officials and people working with community-based, national and international organizations. Four hundred sixty-one people were interviewed. There were 342 men and 119 women in the final sample. The sampling frame was the heads of households living around the three study lakes. The selection of these households was based on simple random sampling using the hat method.

The question regarding whether the community is seeing an improvement in the number of species around the lakes was used as a proxy for successful lake protection outcomes. Education was divided into two categories: formal education, measured by the number of years of schooling, and informal education, measured by the interaction between conservation organizations and the communities with the aim of creating awareness. Awareness of the designation as a Ramsar site and of the existence and role of international, national and local organizations was used a proxy to measure informal education (Polajnar 2008). The designation of these wetlands in itself creates conditions that indicate to the communities that these waters need to be protected. 
The following logistic regression model was developed to predict the impact of specific activities around the lakes on conservation outcomes. The dependent variable was a "yes" or "no" answer to the question of about improvement in the number of species around the lakes. An answer of yes indicates that a specific activity improves the number of species and is assigned a value of 1; no indicates that a specific activity does not improve the number of species and is assigned a value of 0 . Logistic regression modeling was chosen because it is best at estimating binary dependent variables, as shown in equation 1.

$P=\frac{a^{\left(\beta_{0}+\beta X\right)}}{1+a^{\left(\beta_{0}+\beta X\right)}}$

where $\mathrm{P}$ is the probability that a combination of the identified activities around the lake leads to improved protection (measured as changes in the number of species) of the lake. $\mathrm{X}$ is a vector of $\mathrm{n}$ independent activities, $\beta_{0}$ is the intercept parameter and $\beta$ is the vector measuring the change in the number of species.

Factors that often affect biodiversity around inland wetlands include but are not limited to migration, economic activities taking place around these wetlands, the existence of settlements close to water bodies, the educational level of residents, the presence or absence of specific institutions, and awareness and knowledge of the protection of these water bodies. The study used both descriptive and inferential statistics. The predictor variables selected for this model comprised continuous and binary variables. The continuous variables were education level, time lived near the lake, distance of home from the lake, involvement in decision-making and occupation. The binary variables were awareness of the $\mathrm{RC}$ and gender. Improvements in the number and quality of species are an indication of improved lake conditions.

As seen in Table 2, the chi-squared model value of 120.345 with a p-value of 0.000 is statistically significant, while the Hosmer and Lemeshow test chi-squared value of 9.669 with a pvalue of 0.289 is not significant. This is an indication of good model fit. In addition, in 95 cases, the variables for species improvement were correctly predicted, and in 62 cases they were not. Overall, the rate of correct predictions was $60.5 \%$, which is average. Regarding the not improved classification, 18 variables were incorrectly predicted and 151 were correctly predicted; 89.3 
percent of the variables were correctly predicted. The overall correct prediction rate was 75.5 percent, indicating fairly good model fit.

Table 2. Model predictions

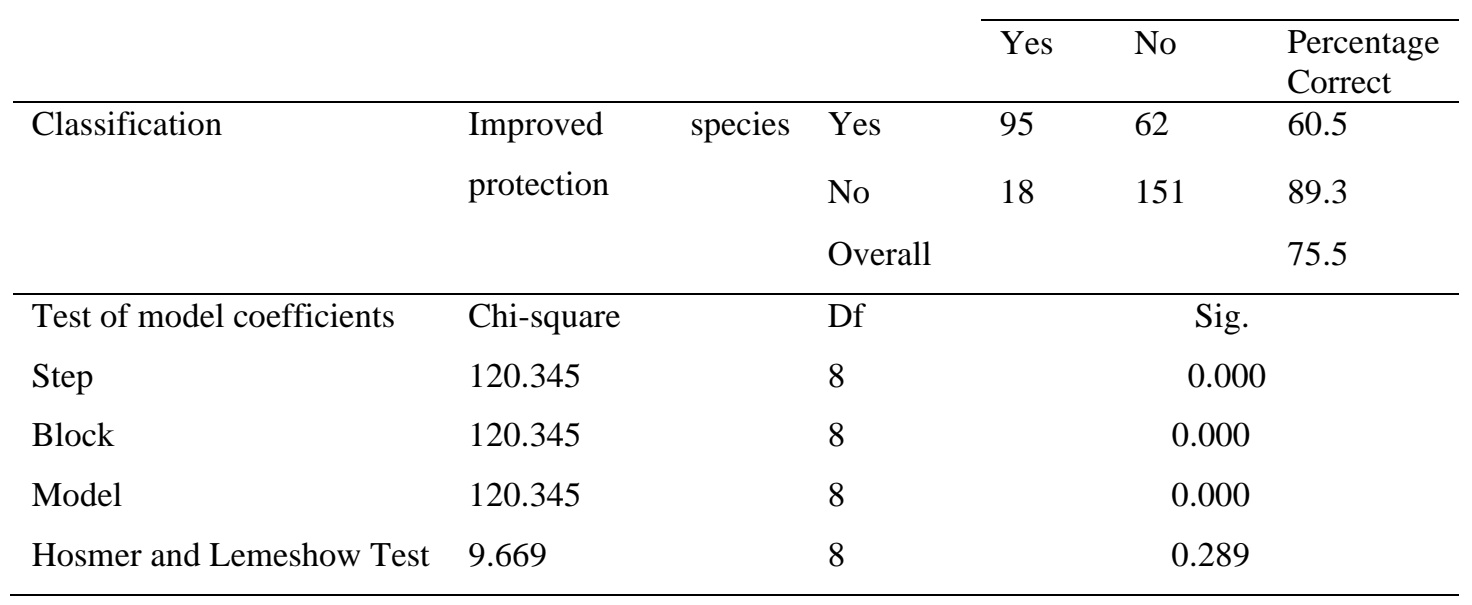

Key variables that have direct bearing on inland wetlands protection were analyzed, and the outcomes are presented in Table 3. How these variables impact species improvement is explained in two ways: by a positive or a negative coefficient and by the odds ratio, $\operatorname{Exp}(\beta)$. A positive coefficient is an indicator of increasing likelihood that a predictor will have a positive impact on species improvement, and vice versa. An odds ratio, $\operatorname{Exp}(\beta)$, of less than one means that the probability that the predictor will lead to species improvement decreases by the value of $\operatorname{Exp}(\beta)$ given a one-unit change in the coefficient. However, an odds ratio greater than one means that the probability that the predictor will lead to species improvement increases by the value of $\operatorname{Exp}(\beta)$ given a one-unit change in the coefficient. For both binary and continuous variables, if the odds ratio is equal to one, there will be no change. However, these changes can only occur if the predictor is significant. The meaning of significant and insignificant variables is explained in the findings section. 
Table 3. Logistic regression outcomes

\begin{tabular}{|c|c|c|c|}
\hline Model Predictor Variables & $\bar{\beta}$ & Sig. & $\operatorname{Exp}(\beta)$ \\
\hline Gender & -0.895 & 0.005 & 0.409 \\
\hline Time stayed near the lake & 0.193 & 0.135 & 1.212 \\
\hline Distance of home from the lake & 0.314 & 0.007 & 1.369 \\
\hline Respondent analysis of lake conditions & -3.886 & 0.000 & 0.021 \\
\hline $\begin{array}{l}\text { Respondent awareness of lead conservation } \\
\text { organization }\end{array}$ & 20.523 & 0.999 & 818308139.325 \\
\hline Public involvement in decision making & 2.733 & 0.000 & 15.374 \\
\hline Educational levels & 0.145 & 0.349 & 1.156 \\
\hline Occupation & -0.007 & 0.816 & 0.993 \\
\hline Constant & -21.936 & 0.999 & 0.000 \\
\hline
\end{tabular}

\section{Findings}

For effective protection of inland wetlands, individual landowners, their communities and local authorities must be engaged and willing to develop and adopt specific policy and wetlands protection initiatives. Often, a stimulating force or an influencing variable, such as education or awareness, must be present through schools, conservation organizations or the government. The designation and the presence of the Kenya Wildlife Service (KWS) or other international conservation organizations should have some significant influence on raising awareness and thus improved wetlands protection. In addition, landowner characteristics such occupations or jobs that people do and institutional awareness in terms why wetlands protection is important are significant components that contribute to successful protection outcomes. The variables related to landowner characteristics and institutional relationship arrangements that are expected to influence communities have been examined. Both significant and nonsignificant variables provide key insights into the underlying factors that influence communities to improve or not improve protection of wetlands and other vulnerable landscapes. The nonsignificant variables are explained first because this is where the real challenge to protecting wetlands and biodiversity generally lies. 


\subsection{Awareness of lead conservation organizations}

The designation of a site is in itself part of the informal education that helps to increase awareness of the need to protect wetlands (Ibrahim et al. 2012; Polajnar 2008). Ramsar designation encourages national and local governments to develop policies and regulations to reduce impacts on wetlands due to human activities. As can be seen from table 3, at the study sites, the awareness of wetlands protection by a lead organization in the communities is nonsignificant at 0.999 , meaning that this has no influence in wetlands protection. This does not confirm our hypothesis that awareness of the role of international, national and local organizations is a significant factor in the protection of inland wetlands. There are three possible reasons for such an outcome: (i) wetlands protection is carried out by national/local organizations and does not give credit to the efforts of RC; (ii) there is no organizational coordination at the local level with clear conservation goals, guidelines and means to engage the community; or (iii) wetlands protection has not become an organizing concept within the local authorities and the community to be used as a constraining policy on settlement and land use activities. It appears that there are no strict land use and settlement regulations being imposed by any organization; therefore, no organization is visible from this perspective.

The institutional focal office for the RC is the KWS. There are other institutions that are involved in assisting the safeguarding of wetlands. These include the National Museums of Kenya (NMK) and the Ministries of Environment, Water and Natural Resources; Planning and Regional Development; Fisheries, Livestock and Agriculture and Education, as well as universities, county councils, and regional development authorities. Other players include the water resource management authorities; non-governmental organizations such as Nature Kenya, Wildlife Clubs of Kenya (WCK) and the World Wildlife Fund (WWF); and governments such as the governments of Japan and the Netherlands. Despite the number of institutions involved, awareness that would enhance wetlands protection was not significant. Based on these findings, the government would need to employ a much stronger and more acceptable approach to protecting the new RC listings.

\subsection{Education}

The variable education level is not significant, as the $\mathrm{p}$ value is 0.349 . This outcome was an indication of the extent to which schools' educational has very little to do with teaching conservation or environmental protection in general and therefore does not influence wetlands 
protection. This fails to confirm the study hypothesis that formal and informational education is a significant factor in the protection of inland wetlands. The analysis of the schools' curriculum is beyond the scope of this study, but the insignificant outcome of the education variable is informative, as it offers insight into the purpose of education throughout the country. The education system is structured almost entirely to develop professionals in the fields of education, accountancy, medicine and law, not environmental sciences. Omission in the education system of the study of the value and conservation of natural resources is and will continue to be a driving force behind the ongoing degradation of wetlands and other vulnerable landscapes. Educating young people about the value of and the need to protect natural resources can facilitate the understanding, awareness and implementation of sustainability not as a concept but as a reality of life.

The characteristics of good quality and quantity of natural resources are based on the fact that these resources are not designed for a purpose from a human perspective but rather have evolved simply to fill an ecological niche in the biosphere (Attfield and Besley 1994, pp. 46). A UNESCO report (2005) on a survey of educational practices at all levels from elementary to postsecondary education found that conservation and sustainable development were not discussed in most schools. The report states that education can distract from sustainability rather than contributing to successful conservation outcomes (Bartels and Parker 2012, pp. 41). Surprisingly, this study confirms these findings from 2005, showing that they are a reality in Kenya's inland wetlands. The educational curriculum is not structured to teach young people to see nature, specifically (in the study) wetlands or other natural resources, as needing to be preserved, only that such resources serve people's needs.

Some studies have shown that although education creates awareness of designated sites, people usually pretend not to know their status until these designated sites are of benefit to them (Gadd 2005). Education does not make any difference in awareness patterns of protected and designated areas until and unless communities are financially secure and obtain economic benefits from them. Several examples of this phenomenon exist within Kenya: around the Laikipia area, where wildlife is abundant and tourism programs engage local communities in ecotourism-related jobs, local people exhibit better awareness of the protected and designated areas. This economic incentive encourages communities to conserve wildlife, especially elephants, as they appreciate 
the link between benefits and conservation. Furthermore, even with education, when communities lose land to the safeguarding of wildlife, they behave as if they are not aware of the protected status of the parks and invade the parks with their livestock. This is the situation on the ground in Lake Bogoria. With a better understanding of the importance of the site, communities gradually develop positive attitudes and acknowledge that they are aware of the protected and designated status of the land through both formal and informal education (Infield and Namara 2001; Gillingham and Lee 1999; Gibson and Marks 1995). However, this varies across individual cases and within countries. For example, in Tanzania and Eastern Botswana, educated communities are more aware of the status of protected areas and the need to conserve both wildlife and wetlands, irrespective of any benefits (Gadd 2003; Harcourt et al. 1986).

\subsection{Occupation}

Occupation is not a significant variable in this region $(\mathrm{p}=0.816)$ in regard to contributing to species improvement around the lakes. This result can again be traced to the system of education. A narrow focus on profession-related outcomes that does not accommodate the greater public good alongside career development for students leads to failure to instill in students the value of natural resources beyond their benefits to humans, such as their fulfilment of ecological functions. This also speaks to the priorities of both the institutions and the people who work for those institutions, as they lack any form of or desire for local environmental protection initiatives or social responsibility values. The RC can present excellent goals for and insights into protecting fragile habitats, but if occupation in local regions remains an insignificant variable, their implementation will undermine conservation efforts.

\subsection{Gender}

In terms of gender, the respondents comprised 342 (74.2\%) males and 119 (25.8\%) females. When this distribution was further broken down by study site, there were 72 (57.6\%) males and 53 (42.4\%) females from Lake Nakuru, 120 (78.9\%) males and 32 (21.1\%) females from Lake Bogoria, and 150 (81.5\%) males and 34 (18.5\%) females from Lake Naivasha.

Gender was found to be a significant negative predictor, and since males were categorized as 1, the findings can be interpreted using the beta variable as indicating that male activities are 0.409 more likely than female activities to bring about degradation of the lake. In this part of the world, 
land belongs to men. In addition, women are excluded from most public management committees and decision-making. Most economic, social and other development decisions that impact the community and, by extension, water resources are male dominated.

\subsection{Distance from home to the lake}

As expected, the further the distance one's home is from wetlands, the higher the chances of species improvement. The findings show that the number of species increases by 0.314 as the home distance from the lake increases by one unit. In addition, the probability of species improvement increases by a factor of 1.369 with a one-unit increase in the distance of a home from the lake. Unfortunately, settlements have been moving closer to water bodies, and more water is being withdrawn for agricultural and other domestic needs. Population growth in these areas ranges from $2.59 \%$ to $2.68 \%$. The major issue going forward is determining the extent to which local communities and authorities have the capacity and are prepared and willing to integrate wetlands protection into settlement and land use regulations. The national government has an established legal framework regarding how close to the lakes people can settle and what activities communities can or cannot conduct. This framework is known as the Environmental Management and Coordination Act (GoK 1999), which states that all buildings should be 30 meters from any water body. However, implementing land use restrictions faces numerous challenges including but not limited to alternative means to meeting basic family needs, weak enforcement and poverty.

\section{6 Public involvement in decision-making}

Public involvement refers to active participation by the community in local and national institutions to influence organizational support for local development that grows communities while protecting natural resources. Effective participation in decision-making requires educational elements that go beyond the narrow focus on career development outcomes to include an understanding of the impact on all other public goods. However, education was found to be an insignificant contributor to the protection of the three lakes in this study. Martinez de Anguita (2014) explains that education is a means of introducing a community to reality, to a deeper understanding of its meaning and discovery capacity, weaknesses and values. Educational contribution should go beyond the instructional focus on resource management to include aspects that can help communities contribute to the common good in addition to pursuing economic development. Education is not a significant variable in this study, which could lead to differing 
actions regarding the protection of these lakes and calls for appropriate engagement with the communities to implement more effective actions.

\subsection{Institutional characteristics}

The nature of local institutional mobilization should be a salient example of how the RC is felt locally through the implementation, in solidarity with the communities and people around the study lakes, of conservation activities that reach all stakeholders. As can be seen in table 3, public involvement is significant and positive. However, the awareness of the lead conservation organization, educational levels and occupation (jobs that people hold) were not significant in protecting wetlands. This is an indication that conservation has not been adequately integrated into educational and occupations to help institutions to make right decisions that mitigate uncontrolled settlements and support conservation. The finding that the majority of people interviewed were not aware of the RC is itself an institutional weakness of the local implementing organizations that cuts two ways. Either these organizations have not understood or clearly explained the RC global goals to the communities or they do not adequately present local community problems to both the national and international community such that specific local challenges can be addressed.

The Water Resource Users Associations formed under the Water Act (GoK 2002) have been brought on board to contribute wider knowledge on the importance of these wetlands. They have developed water catchment plans and are involved in training people on the importance of water conservation and the implementation of Article 5 of the RC. The extent to which this local effort has succeeded in developing an effective stakeholder platform for participation is clearly in question when so many people are not aware of the RC. Again, participation alone, when settlement near the lakes has actually been on the rise and when communities have not been provided with choices, paints a grim picture for wetlands protection.

\section{Discussion}

From an educational perspective, the challenge to conservation arises from the fact that, as can be seen from figure 2 , there is a very small percentage of people who have attained education beyond the secondary (high school) level. People with low levels of education may not be able to adequately establish a connection between international policy and local wetlands protection (Breitmeier et al. 2006 pp 191; Gadd 2005). Knowledge should not be underestimated because 
when local communities need to make choices and understand tradeoffs, educational skills are extremely important (UNESCO 2005). Education at the secondary level and below that is geared towards understanding mathematics and English and has a very shallow focus on the broader society and management of public affairs will not significantly support conservation. The overall results in the Ramsar sites of Lakes Nakuru and Naivasha indicated that those with higher levels of education were more aware of the Ramsar sites than those with low levels of education.

Figure 2. Education levels of respondents around the study lakes

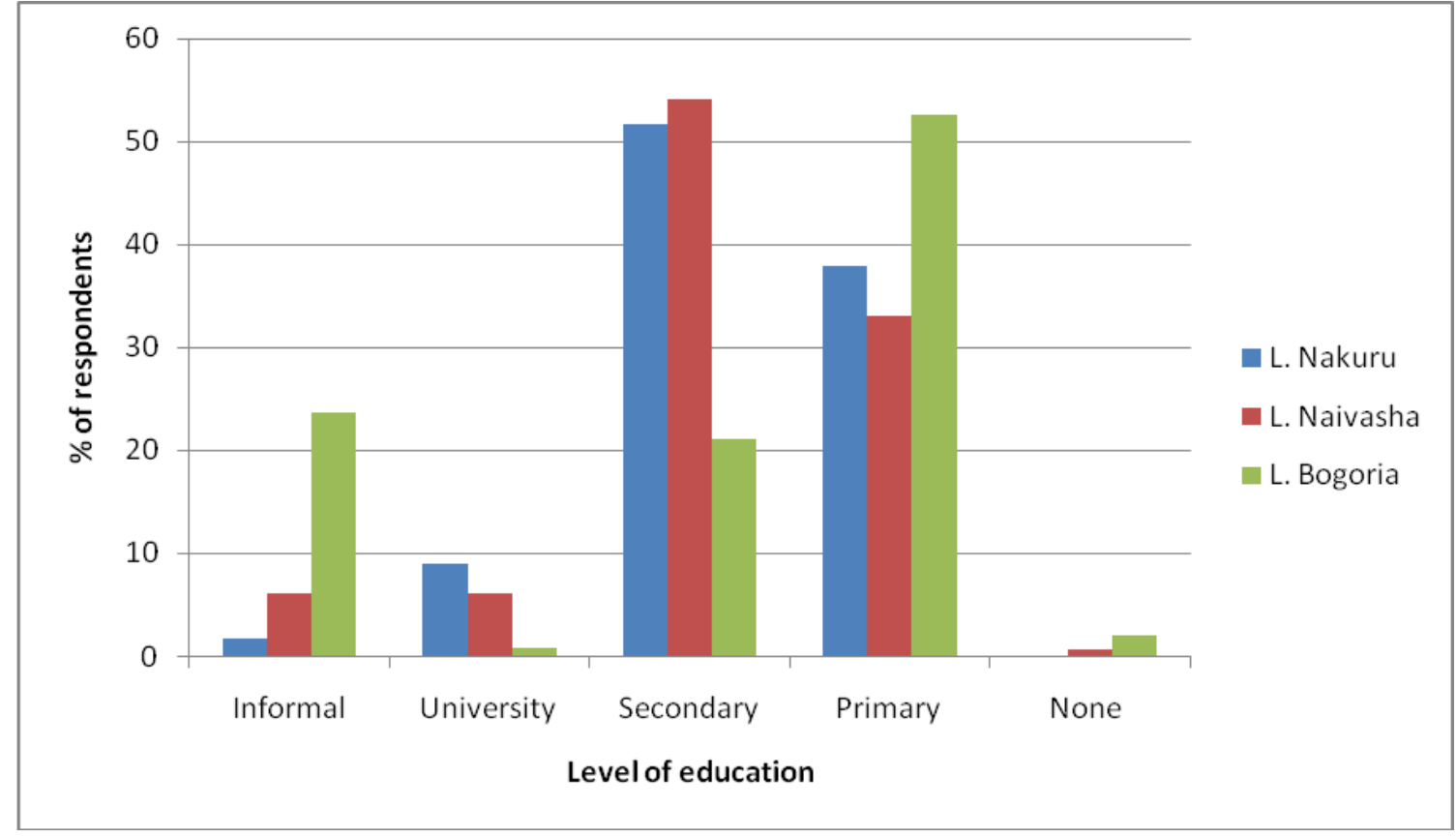

Source: Field survey

Experience from other regions shows that education accompanied by outreach programs has a substantial effect on awareness creation. Studies carried out around the Cape Peninsula in Australia, Mackenzie Delta in Canada and Lake Mburo National Park in Uganda have shown that community outreach programs and education around protected areas are very important for sensitization (Holmes 2003; Infield and Namara 2001). According to Norton-Griffiths (2000), when communities around protected areas benefit from community outreach programs coordinated by schools and national institutions, they safeguard natural resources better.

Findings that many local residents in the three regions are not aware of the $\mathrm{RC}$, as shown by the insignificant regression results, despite the $\mathrm{RC}$ designation of the lakes raises many questions. 
Either the global policies are not being contextualized properly in local settings or the local institutions are not adequately treating these lakes as resources of global, not just local, importance. This also weakens the pillar of international cooperation on the management of shared resources, knowledge and information. Local communities will see a local institution and local institutions will see a national, regional or international institution when global policies are contextualized at both national and local levels (Atisa 2020a). This situation calls for further reexamination of the roles of local governments and conservation organizations in the eyes of local communities.

The protection of wetlands by local communities and local authorities is an extension of the policies developed by the RC and passed down to national governments. Without a doubt, international conservation organizations have engaged in a sustained mobilization of efforts globally that has been far-reaching (Davidson 2018; Gray et al. 2013; Gardner and Davidson 2011). These efforts have seen Kenya sign onto and agree to the RC goals for wetlands protection, but the country has not yet developed an organizing concept to inform local communities of the impact of settlements around wetlands. Inland wetlands cannot be managed in isolation from community needs. Moreover, low education levels among the majority of community members reduces their effective participation in decision making in wetlands protection policies (Kumar et al. 2015; Wever et al. 2012).

In regions where communities directly depend on natural resources and the land for their basic needs, it is highly likely that designation alone is enough to enhance protection (Do et al. 2015). It is the responsibility of local institutions to provide choices and tradeoffs and inform communities about the RC classification of wetlands. For example, while land use regulations are critical in managing settlements near fragile landscapes, these will be resisted by communities if those affected are not presented with alternative economic choices for providing for their basic needs (Nemutamvuni et al. 2020). Around these three lakes, local communities have not been provided with economic choices and have therefore continued to settle very close to the lakes and to engage in harmful land use activities.

The extent that the $\mathrm{RC}$ is able to influence national and local governments and communities to see value and opportunities in protecting wetlands is called into question by the finding that the educational system was not a significant factor. The role that should be played by local authorities 
in the uptake of specific conservation efforts by communities in terms of creating awareness seems not to have been promoted to the level of visibility such that it can significantly influence communities. Educational training can provide a foundation for promoting conservation and can extend to the development of local experts wanting to be involved in understanding and actively articulating conservation policies to their own people.

The national government must empower local institutions to rise up and take the lead in wetlands protection, as these are the entities with local knowledge, an understanding of local needs and the ability to explain the value of protecting fragile habitats to communities. While the significant and insignificant factors identified in this study cannot entirely explain what would be required to protect these study lakes, they do offer a window into the real challenges facing these inland wetlands. Wetlands are priceless ecosystems that occupy $6 \%$ of the world's surface (Kotios et al. 2009). Wetlands are very important to Kenya, where they cover $14,000 \mathrm{~km}^{2}$ (3\% of the land surface) (Ministry of Environment and Mineral Resources 2012). They contribute greatly to national development in terms of tourism, food production, culture, transportation, recreation, grazing, education and research (Horwitz \& Finlayson 2011). In spite of this value, they continue to be degraded and lost to agriculture and other development activities, as most people perceive wetlands as wastelands (Shah 2016).

Wetlands play a critical role in both rural and urban livelihoods, especially the former, maintaining ecosystem balance through nutrient and carbon cycling and safeguarding biodiversity (Ratner et al. 2004). Most of these wetlands are found outside protected areas and, as a result, continue to face serious threats from population increase, deforestation, overgrazing and invasive species. However, little has been done to reduce this decline (Butchart et. al. 2010), and when efforts are made, these efforts come short. If wetlands are used sustainably, they can contribute to biodiversity conservation and improve the security of local communities. This is in line with the Biodiversity Strategic Plan 2011-2020 and the Aichi Targets (UNEP 2012). In recent years, efforts to safeguard wetlands have been made by setting up more wetlands as protected areas (Horwitz et al. 2011) and providing education and creating awareness of these wetlands (Finlayson et al. 2014). However, as the findings from this study indicate, the nature and type of education being provided do not support efforts to protect wetlands. 
The insignificant variables are critical to wetlands protection, and ways to help them start to contribute to improved biodiversity must be found. In doing so, there is a need for educational reforms so that career development is not narrowly focused on career interests but encompasses broader general awareness raising and training in environmental conservation.

\section{Conclusions}

As Gray et al. (2014) explain, managing wetlands is a complex process requiring an understanding of ecosystem processes, hydrology, species and principles of wildlife management. Such an understanding can come primarily through education and awareness. This entails obtaining the right education through schooling and training and gaining awareness from interactions among institutions, experts and local communities. However, education and awareness variables were found to be insignificant at the three study sites. In addition, as shown in figure 2, the majority of respondents have low education levels. This answers the research question, and it is therefore safe to conclude that $\mathrm{RC}$ designation and formal and informal education do not support communities and institutional efforts in the protection of inland wetlands. As a result, wetlands in Kenya will likely to continue to face degradation pressures and will decline in quality and size over time.

As it stands now, there is goodwill to protect wetlands in Kenya, as can be seen by the number of government and international institutions involved. The key challenges seem to come from the fact that many local authorities do not have the right educational knowledge or sufficient awareness to develop the technical capacity to make a real positive difference in local conservation on their own. The classification of wetlands as RC-protected alone is not sufficient; it is the first step in a long series of activities needed to protect wetlands. Institutions operating at local levels, such as the KWS, WCK, WWF and Ministry of Education, despite their good mobilization partnership with the RC, also need discrete conservation partnerships with local communities that link international and national conservation policies to local conservation challenges. This can only be achieved if the communities are well educated and aware of the reasons behind efforts to protect wetlands.

The RC relies on "wise use" as one of the pillars of wetlands protection. The implementation of this pillar and the protection of wetlands is problematic in the communities near the three inland lakes studied. Most people surveyed were not aware of the existence of the RC, meaning that they 
might not be aware of the three pillars of "wise use," "designation" and "sharing of knowledge and resources". No specific requirements mandating local communities to comply with specific and identifiable "wise use" approaches to wetlands exist, as can be inferred from the insignificant regression outcome of the awareness variable. In addition, the education system is structured almost entirely to develop professionals in the fields of education, accountancy, medicine and law rather than in environmental sciences. Effective participation in decision-making requires educational elements that go beyond the narrow focus on career development outcomes to include an understanding of the impact on all other public goods. We can therefore conclude that conservation has not been adequately integrated into educational and institutional goals to mitigate uncontrolled settlement and inform people's views regarding wetlands protection.

\section{Limitations of the study}

While there can be several limitations in a study that looks at environmental conservation, one that is key to this study is that we did not analyze the current educational curriculum. Education was found to be insignificant as a factor contributing to wetlands protection, but analysis of the curriculum itself was outside the scope of this study. Another limitation is related to the idea that effective protection of wetlands can also be achieved through incentives, coercion or regulations. Our study did not examine various incentives, coercion mechanisms or regulations that could be used alongside educational and awareness. We recommend that future studies analyze the school curriculum and examine various incentives, coercion mechanism and regulations that could be used to better protect these wetlands. This can be done with an understanding that this might not be possible in an environment where communities have limited alternatives to meeting their basic needs. Future studies should identify the types of incentives, coercion or regulations that can support wetlands protection while ensuring that communities are not deprived of their means of livelihood. These are discussions that are beyond the scope of this study at this time. 
References

Alvarado-Quesada, G., \& Weikard, H-P. (2017). International environmental agreements for biodiversity conservation: A game-theoretic analysis. International Environmental Agreements, 17, 731-754.

Atisa, G. (2020a). Policy adoption, legislative developments, and implementation: the resulting global differences among countries in the management of biological resources. International Environmental Agreements, 20, 141-.

Atisa, G. (2020b). Using historical information and data to strengthen planning for environmental protection and management at Everglades National Park, South Florida. Journal of Environmental Studies and Sciences, 10(2), 124-136.

Atisa, G., Bhat, M. G., \& McClain, M. E. (2014). Economic assessment of best management practices in the Mara River Basin: Towards implementing payment for watershed services. Journal of Water Resources Management, 28, 1751-1766.

Attfield, R., \& Besley, A. (1994). Philosophy and the natural environment. Royal Institute of Philosophy Supplement: 36. Cambridge University Press.

Bartels, K. A., \& Parker, K. A. (2012). Teaching sustainability/teaching sustainably. Stylus Publishing.

Becht, R., \& Harper, D. M. (2002). Towards an understanding of human impact upon the hydrology of Lake Naivasha, Kenya. Hydrobiologia, 488, 1-11.

Bowman, M.J. (1995). The Ramsar Convention comes of age. Netherlands International Law Review, XLII, 1-52.

Breitmeier, H., Young, O. R., \& Zurn, M. (2006). Analyzing international environmental regimes: From case study to database. The MIT Press.

Bridgewater, P. (2008). A new context for the Ramsar Convention: Wetlands in a changing world. RECIEL, 17(1), 465.

Butchart, S. H. M., Walpole, M., Collen, B., van Strien, A., \& Schalemann, J. P. W. (2010). Global biodiversity: Indicators of recent decline. Science, 328(5892), 11641168.

Davidson, N. C. (2018). Biodiversity-related Conventions and initiatives relevant to wetlands. The Wetland Book. Springer.

De Troyer, N., Mereta, S. T., Goethals, P. L., \& Boets, P. (2016). Water quality assessment of streams and wetlands in a fast-growing East African City. Water, 8(4), 123

Do, Y., Kim, J. Y., Lineman, M., Kim, D., \& Joo, G. (2014). Using internet search behavior to assess public awareness of protected wetlands. Conservation Biology, 29(1), 271-279 
Everard, M., \& Harper, D. (2002). Towards the sustainability of the Lake Naivasha Ramsar site and its catchment. Hydrobiologia, 488, 191-203

Fernández, B. G., \& Emeterio, G. S. (2017). Conceptions and perceptions of primary school teachers on wetlands. Wetlands, 37, 1045-1053

Finlayson, C. M., Bartlett, M., Davidson, N., \& Mclnnes, R. (2014). The Ramsar Convention and urban wetlands: An opportunity for wetland education and training. Secretariat of the Ramsar Convention.

Gadd, M. E. (2003). Elephant ecology and conservation in African rangelands. Ph.D. Dissertation, University of California at Davis, CA, USA.

Gadd, M. E. (2005). Conservation outside of parks: Attitudes of local people in Laikipia Kenya. Environmental Conservation, 32(1), 50-63

Gardner, R. C., \& Davidson, N. C. (2011). The Ramsar convention. In C. Max Finlayson, M. Everard, K. Irvine, R. J. McInnes, B. A. Middleton, A. van Dam, \& N. Davidson (Eds.), The wetland book structure and function, management, and methods (chapter1).Netherlands: Springer.

Gibson, C. C., \& Marks, S. A. (1995). Transforming rural hunters into conservationists: An assessment of community-based wildlife management programs in Africa. World Development, 23, 941-957

Gillingham, S., \& Lee, P. C. (1999). The impact of wildlife-related benefits on the conservation attitudes of local people around the Selous Game Reserve, Tanzania. Environmental Conservation, 26, 218-228

GoK. (1999a). Environmental Management and Coordination Act (EMCA). Government Printer, Nairobi.

GoK. (1999b). Sessional Paper No. 6 on Environment and Development. Government Printer, Nairobi.

GoK. (2002). The Water Act. Government Printer, Nairobi.

GoK. (2010). The National Constitution of Kenya. Government Printer, Nairobi.

GoK. (2013a). Environment Policy. Government Printer, Nairobi.

GoK. (2013b). Wetlands Conservation and Management Act. Government Printer, Nairobi.

GoK. (2015). The Wetlands Conservation and Management Policy. Government Printer, Nairobi.

GoK. (2017). Environmental Management and Coordination (Conservation and Management of Wetlands) Amendment Regulations. Government Printer, Nairobi. Gray, M. J., Hagy, H. M., Nyman, J. A., \& Stafford, J. D. (2013). Management of wetlands for wild-life. In J. T. Anderson \& C. A. Davis (Eds.), Wetland techniques (volume 1) Applications and management. London: Springer. 
Harcourt, A. H., Pennington, H., \& Weber, A. W. (1986). Public attitudes to wildlife and conservation in the third world. Oryx,20, 152-154

Holmes, C. M. (2003). The influence of protected area outreach on conservation attitudes and resource use patterns: A case study from Western Tanzania. Oryx,37, 305-315

Horwitz, P., \& Finlayson, C. M. (2011). Wetlands as settings: Ecosystem services and health impact assessment for wetland and water resource management. BioScience, 61, 678-688

Horwitz, P., Finlayson, C. M., \& Weinstein, P. (2011). Healthy wetlands, healthy people: A review of wetlands and human health interactions. Secretariat of the Ramsar Convention on Wetlands and the World Health Organisation. Ramsar technical report No. 6, Gland, Switzerland.

Ibrahim, I., Aminudin, N., Young, M. A., \& Yahya, S. (2012). Education for wetlands: Public perception in Malaysia. Procedia - Social and Behavioral Sciences,42, 159165

Infield, M., \& Namara, A. (2001). Community attitudes and behaviour towards conservation: An assess-ment of Lake Mburo National Park, Uganda. Oryx,35, 4860

Kotios, A., Plageras, P., Galanos, G., Koutoulakis, M., \& Saratsis, U. (2009). The impact of tourism on water demand and wetlands: Searching for a sustainable coexistence. Discussion Paper Series, 15(4), 71-88

Kumar, K., Singh, N. M., \& Kerr, J. M. (2015). Decentralization and democratic forest reforms in India: Moving to a rights-based approach. Forest Policy and Economics,51, 1-8

KWS. (2002). Lake Nakuru Integrated Ecosystem Management Plan 2002-2012.

Netherlands Government, KWS, MCN, WWF, Moi University and University of Nairobi.

KWS. (2005a). Information Sheet on RAMSAR Wetlands. KWS, Nairobi.

KWS. (2005b). KWS Strategic Plan 2005-2010. KWS, Nairobi.

KWS. (2011). National wetlands inventory and mapping. KWS, Nairobi.

KWS. (2012). National report on the implementation of the Ramsar Convention on Wetlands. Nairobi: KWS.

Macharia, J. M., Thenya, T., \& Ndiritu, G. G. (2010). Management of highland wetlands in central Kenya: The importance of community education, awareness and eco-tourism in biodiversity con-servation. Biodiversity,11(1-2), 85-90

Loucks, D. P., \& van Beek, E. (2017). Water resources planning and management: An 
overview. In D. P. Loucks \& E. van Beek (Eds.), Water Resource Systems Planning and Management (chapter 1). (pp. 1-49). Springer.

Maltby, E. (1986). Why waste the world's wet places. IIED and Earthscan.

Martinez de Anguita, P., Martin, M. A., \& Clare, A. (2014). Environmental subsidiarity as a guiding principle for forestry governance: Application to payment for ecosystem services and REDD+ architecture. Journal of Agricultural and Environmental Ethics, 27, 617-631

Mathews, G. V. T. (2013). The Ramsar Convention on wetlands: Its history and development. The Ram-sar Convention Bureau, Gland, Switzerland.

Millennium Ecosystems Assessment. (2005). Ecosystems and well-being: Biodiversity synthesis. Island Press.

Ministry of Environment \& Mineral Resources. (2012). Kenya wetlands atlas. GoK, DANIDA and UNEP.

Mitsch, W. J., \& Gosselink, J. G. (1993). Wetlands. Van Nostrand Reinhold.

Nemutamvuni, K., Mckay, T.J.M., \& Tanton, H.B. (2020). Active citizenry, community - Based organi-sations and the protection of urban wetlands: The case of colbyn, Tshwane, South Africa. Global Ecology and Conservation, 24.

Norton-Griffiths, M. (2000). Wildlife losses in Kenya: An analysis of conservation. Natural Resource Mod-elling,13(1), 13-34

Owino, A. O., Oyugi, J. O., Nasirwa, O. O., \& Bennun, L. A. (2001). Patterns of variation in waterbird num-bers on four Rift Valley lakes in Kenya, 1991-1999. Hydrobiologia,458, 45-53

Peck, D. (2008). Kenya adds 2 sites to the Montreux Record. Retrieved June 2019 from http:// www. pgai. or. kr/ pga/ board. hp? board $=$ engli sh\& page $=7 \&$ comma nd $=$ body $\&$ no $=64 \&$ PHPSE SSID $=9225 \mathrm{c}$ df1391b678 ba8aa 522c2 3f38c 0d.

Polajnar, K. (2008). Public awareness of wetlands and their conservation. Acta Geographica Slovenica,48, 121-146

Raimondo, S., Sharpe, L., Oliver, L., McCaffrey, K. R., Purucker, S. T., Sinnathamby, S., \& Minucci, J. M. (2019). A unified approach for protecting listed species and ecosystem services in isolated wetlands using community-level protection goals. Science of the Total Environment,663, 465-478

Raini, J. A. (2009). Impact of land use changes on water resources and biodiversity of Lake Nakuru catchment basin Kenya. African Journal of Ecology, 47(1), 39-45

Ramsar Convention on Wetlands. (2015). Ramsar briefing note 7 State of the world's wetlands and their services to people: A compilation of recent analyses. Ramsar COP 12. 
Ratner B. D., Ha, D. T., Kosal, M., Nissapa, A., and Chanphengxay, S. (2004). Undervalued and overlooked: Sustaining rural and livelihoods through better governance of wetlands. Working Papers. World Fish Center Studies and Reviews. 28

Russi, D., ten Brink, P., Farmer, A., Badura, T., Coates, D., Förster, J., Kumar, R., \& Davidson, N. (2013). The economics of ecosystems and biodiversity for water and wetlands. London and Brussels: Institute for European Environmental Policy.

Shah, P. S. (2016). Domestication and application of biodiversity related multilateral environmental agreements (MEAs) in Kenya. PhD Thesis, University of Nairobi. Shah, P. S. (2020). Domestication of the Ramsar Convention in Kenya. In M. Ogot, W. Mitullah, K. Kanyinga, W. Jaoko, R. Ayah, P. Ngau, G. Rading, T. KiritiNganga, P. Kameri-Mbote, A. Warris, D. Olago, T. Waema, W. Akala \& J. Ambuko (Kenya Policy Briefs). Towards realizing of Vision 2030. Office of the DVC Research, Innovation and Extension. University of Nairobi. pp 13-14.

Smaldone, D. (2013). Planning interpretive and education programs for wetlands. Book Chapter in Anderson J. T., and Davis, C. A. (2013). Wetland Techniques Volume 3: Applications and management. Springer Dordrecht Heidelberg New York London. Thew, H. (2018). Youth participation and agency in the United nations framework convention on climate change. International Environmental Agreements, 18, 169189

Weitzman, M. L. (1998). The Noah's Ark problem. Econometrica, 66(6), 1279-1298

Wever, L., Glaser, M., Gorris, P., \& Ferrol-Schulte, D. (2012). Decentralization and participation in integrated coastal management: Policy lessons from Brazil and Indonesia. Coastal and Ocean Management, 66, 63-72

WWF. (2000). WWF project technical progress report. Nairobi: WWF - Eastern Africa Regional Programme Office.

WWF. (2011a). Lake Bogoria basin: Conflict creates an opportunity for constructive dialogue, conservation and agricultural development - Synthesis of status, key results and lessons learnt. Kenya County Office, WWF.

WWF. (2011b). Shared risk and opportunity in water resources: Seeking a sustainable future for Lake Naivasha. WWF.

UNEP. (2012). United National Environmental Program. Global Environment Outlook 5 (GEO 5).

UNESCO. (2005). Literacy for Life. UNESCO. 